\title{
Denys-Drash Syndrome
}

National Cancer Institute

\section{Source}

National Cancer Institute. Denys-Drash Syndrome. NCI Thesaurus. Code C84668.

A rare congenital syndrome caused by mutations in the WT 1 gene. It is characterized by the presence of congenital nephropathy (diffuse mesangial sclerosis), Wilms tumor, and intersex disorders. 